\title{
A case report of giant rhinophyma
}

\section{Giorgio Cabrini*, Pasquina La Torre, Antonio Buonamico, Giampaolo Quaternato, Letizia Neri and Giampiero Neri}

Department of Neuroscience, Imaging and clinical Sciences, University “G. D’Annunzio” of Chieti-Pescara, Hospital “S.S. Annunziata”, Via dei Vestini, 66100 Chieti, Italy

\begin{abstract}
Introduction: We present the case of a man with a giant rhinophyma, a very rare nasal disorder.

Case presentation: A 89 years old man had been observing a rapid increase in the size of the nose in the last eight years. He had been reporting difficulty in breathing through the nose and mouth and intaking food for months. The aesthetic aspect, severely compromised, had determined the isolation of the subject even from family members.

We decided to operate the rhinophyma completely by using sharp scalpel incision and electrosurgical knife assisted dissection. Histological examination of the biopsy specimens revealed a hyperkeratosis of the epidermis and cystic expansion of ducts in dermis. After excision, the recovery of normal physiognomy has led to the recovery of social and family relationships.
\end{abstract}

Conclusion: In our experience it affords the surgeon the ability to rapidly and accurately sculpt the nose to an excellent aesthetic result. In advanced forms of rhinophyma, when the tumor is giant, the main method of treatment is surgery.

\section{Introduction}

Rhinophyma is a rare, disfiguring disease characterized by a progressive hypertrophy of the soft-tissues of the nose with its increased volume, mainly in the lower half, and often associated to an end-stage of severe acne rosacea [1]. In literature only 18 cases of giant rhinophyma are described [2-19] (Table 1).

The disease typically affects the lower two thirds of the nose and rarely shows malignant degeneration [20]. There is a $15-30 \%$ simultaneous development of rhinophyma and carcinoma in literature, and the most common associated carcinoma is basal cell carcinoma. It can also cause upper airways obstruction and difficulty in eating [21]. Rhinophyma primarily affects caucasian men in the fifth to seventh decades of life, with a male-female ratio of $12: 1$, while it's slightly

Table1. Literature of cases of giant rhinophyma

\begin{tabular}{|l|l|c|}
\hline Author & Year & Number of cases \\
\hline Wójcicka K, [2] & 2018 & 1 \\
\hline Antunes M, [3] & 2017 & 1 \\
\hline Wolter A, [4] & 2017 & 1 \\
\hline Novati FC, [5] & 2015 & 1 \\
\hline Sahin C, [6] & 2014 & 1 \\
\hline Lazzeri D, [7] & 2013 & 1 \\
\hline Popa D, [8] & 2012 & 1 \\
\hline Mangal M, [9] & 2012 & 1 \\
\hline Mustafaev DM, [10] & 2011 & 1 \\
\hline Akhdari N, [11] & 2009 & 1 \\
\hline Köse R, [12] & 2008 & 1 \\
\hline Nambi GI, [13] & 2008 & 1 \\
\hline Blairvacq JS, [14] & 2008 & 1 \\
\hline Sharma R, [15] & 2005 & 1 \\
\hline Racić G, [16] & 1999 & 1 \\
\hline Izu R, [17] & 1994 & 1 \\
\hline Giliarovskaia GB, [18] & 1968 & 1 \\
\hline Debidour, [19] & 1952 & \\
\hline
\end{tabular}

present in black race. A genetic predisposition in English and Irish descents is common. While the etiology is unknown, it is believed that an infection or an inflammatory process is occurring and a parasite as Demodex folliculorum may be responsible for this disorder. It has been reported that the excess of steroid hormones (androgens), gastric disorders, spicy foods, stress, caffeinated products, and alcohol may contribute to this disease.

In the past the rhinophyma was considered a clinical sign of alcoholism, but this relationship was never demonstrated [22,23].

Rhinophyma is characterized by lobulated overgrowth of sebaceous glands and connective tissue; the peculiar morphologic characteristics of rhinophyma are: (1) teleangectasie, (2) hypervascularity, (3) a thick nasal cutaneous layer, (4) nodularity covered by atrophic skin with expanded pores.

Histopathologically, two forms of rhinophyma are described in literature by Tope et al. [24]. The most common one is characterized by histological lesions, that are peculiar of rosacea, the other one is the "fibrous variant." In the first case, we can observe massive hyperplasia of sebaceous glands, elastosis in the derma, moderate fibrousness with collagen fibers plunged in a mixoid edematous stroma, many follicular cysts, and lympho-histocyte infiltration around expanded blood vessels. In the fibrous variant, we can observe severe fibrotic alterations in the derma, decrease or lack of sebaceous glands, and dermal annexes

${ }^{\star}$ Correspondence to: Giorgio Cabrini, Department of Neuroscience, Imaging and clinical Sciences, University "G. D'Annunzio" of Chieti-Pescara, Hospital "S.S. Annunziata", Via dei Vestini, 66100 Chieti, Italy, Tel: +39-087-135-71; E-mail: giorgio2090@gmail.com

Key words: crhinophyma, giant rhinophyma, hypertrophy of the nose

Received: January 21, 2019; Accepted: February 08, 2019; Published: February 13, 2019 
According to these clinical data, El-Azhary et al. [25] classified the rhinophyma in low, moderate, and severe degree of disease when it's possible to find teleangectasie and low hypertrophy of cutaneous layer in the first case, moderate hypertrophy and small nodularities in the second case, massive nodularity in the severe form.

Medical treatment, when used, is usually undertaken before and in conjunction with surgical treatment. This latter includes total eradication (full thickness excision) or subtotal eradication (partial thickness excision, superficial decortication) of the diseased tissue.

Total eradication (down to the loose areolar layer overlying the osteocartilaginous scaffolding) and the following covering with skin grafts or flaps, are necessary for deeply infiltrating rhinophyma, rhinophyma with underlying neoplasia, or fibrous variant rhinophyma, where excessive fibrous tissue make a partial thickness excision difficult.

Subtotal eradication by tangential excision of diseased tissue, preserves the underlying sebaceous gland and allows a spontaneous reepithelization that is not only a less complicated surgical procedure, but it also guarantees a complete healing with better aesthetic results in two to three weeks, although a low risk of recurrence remains [21,26,27].

Dermaplaning and dermabrasion have had long-standing popularity with favorable results. Other modern techniques include electrocautery, laser ablation, ultrasonic scalpel ablation and radio frequency blade vaporization. The major complications of rhinophyma surgery includes exposure or destruction of cartilage leading to chondritis.

\section{Case report}

An 89-year-old man presented to the otolaryngology department of Santissima Annunziata hospital complaining of nasal deformity (Figure 1). The patient noticed slowly progressive thickening of the nose skin about 8 years ago. He claimed rapid growth of the mass in the last two years. His medical history revealed neither alcoholism nor any dermatological disease.

On physical examination, there was a large, pedunculated, swollen, firm, irregular mass of $12 \mathrm{~cm} \times 7 \mathrm{~cm} \times 8 \mathrm{~cm}$ in size, occupying the area of the tip, dorsum and both alae of the nose.

The nostrils and the mouth were partially obstructed, causing breathing and feeding difficulties. The remaining head and neck examination were normal.

Its size at presentation caused cosmetic embarrassment and obstructed the nares. Because of his unaesthetic aspect, the patient was excluded from his family and his group of friends. His family doctor advised against the surgery due to the age. He scored 45 points at the Beck Depression Inventory that indicates a severe depression (Figure 2).

The lesion was completely excised in monoblock by using sharp scalpel incision and electrosurgical knife assisted dissection under local anesthesia. The rhinophyma was incised until the perichondrium of the nasal structure is reached. The perichondrium and periosteum of the osteo-cartilaginous tissue were preserved (Figure 3).

The wound was treated with local doxycycline therapy daily. Three weeks after the surgery, wound epithelization was completed. (Figure 4).

On histopathological examination of the biopsy specimens, hyperkeratosis of the epidermis and cystic expansion of ducts in dermis was observed. The sebaceous glands were increased in size and number. Fibrosis and chronic lymphoplasmacytic cell infiltration were observed around the ducts. Neoplastic cells were not seen. There were

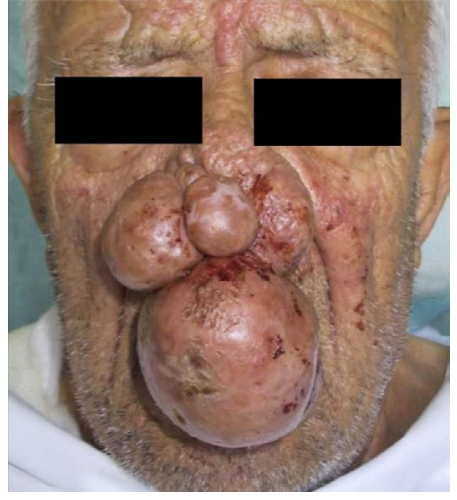

Figure 1. Nasal deformity

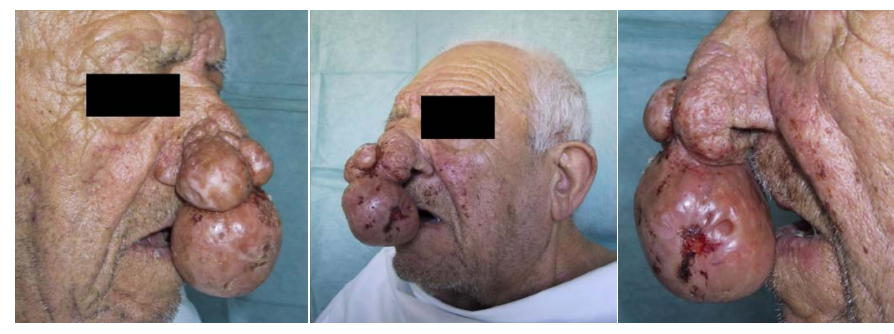

Figure 2. Cosmetic embarrassment and obstructed the nares
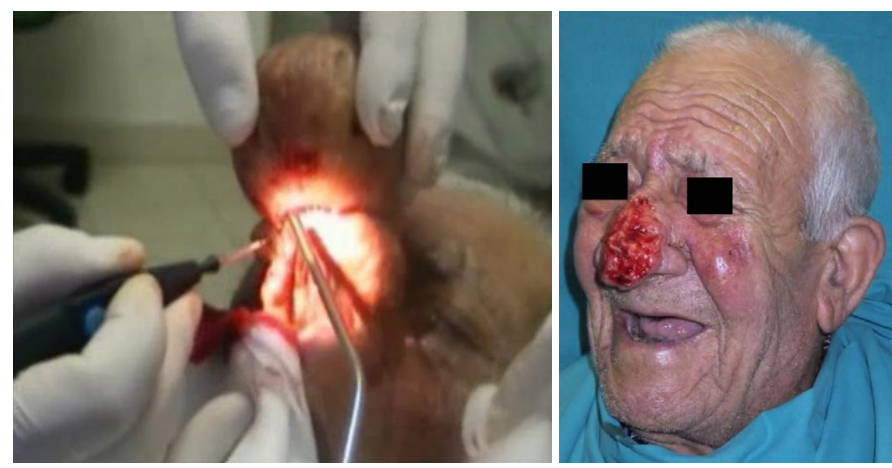

Figure 3. Removal of lesion by using sharp scalpel incision and electrosurgical knife

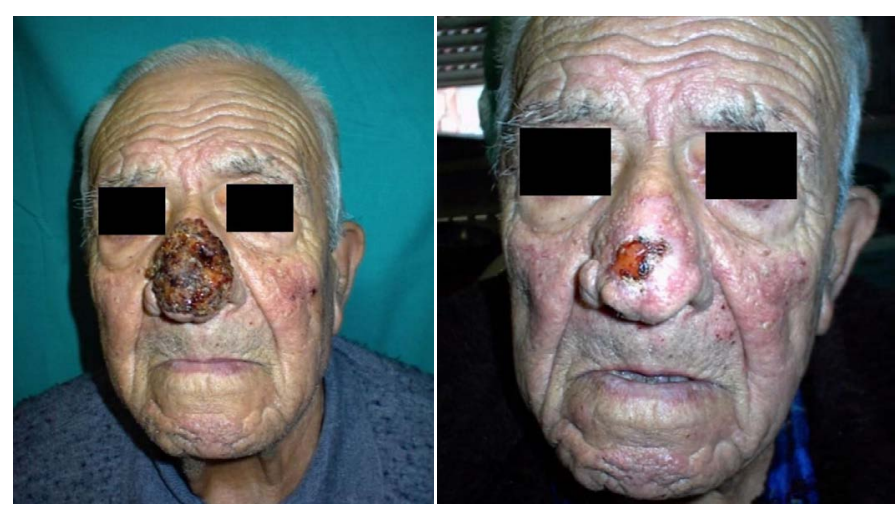

Figure 4. Wound epithelization

telangiectatic vessels throughout the structure and marked lymphocytic inflammatory reaction (Figure 5).

No recurrence was seen during follow-up period; one year after surgery, the result was functionally and cosmetically acceptable to the patient, with the recovery of social and family relationship and an improvement of the depressive state (Beck Depression Index $=10$ ). 


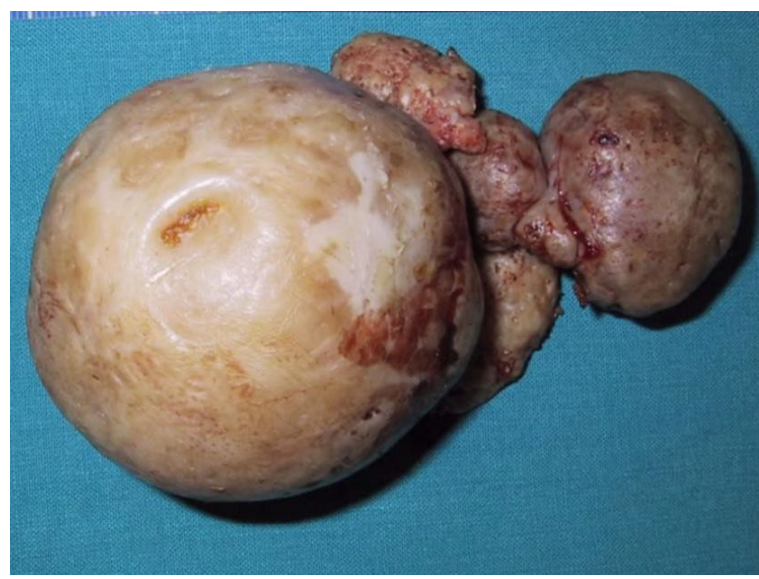

Figure 5. Telangiectatic vessels and marked lymphocytic inflammatory reactiona

\section{Conclusion}

Rhinophyma represent stage IV of rosacea acne, that give an unaesthetic aspect of nose and of face too. Medical management generally has disappointing results, except in the very early stages of photomatic change. The histopathological exam is very useful to establish a certain diagnostic and lesions progression. In the last twenty years only 18 cases of giant rhinophyma were described; according to our experience mass dimension do not interfere with the surgery that can be provided under local anesthesia.

\section{References}

1. Clarós P, Sarr MC, Nyada FB, Clarós A (2018) Rhinophyma: Our experience based on a series of 12 cases. Eur Ann Otorhinolaryngol Head Neck Dis 135: 17-20. [Crossref]

2. Wójcicka K, Żychowska M, Yosef T, Szepietowski J (2018) Tangential Excision Followed by Secondary Intention Healing as a Treatment Method for Giant Rhinophyma-Simple, Safe, and Effective. Dermatol Surg. [Crossref]

3. Antunes E, Schumann J, Brodie G, Jacob MV, Schneider PA (2017) Biochar produced from biosolids using a single-mode microwave: Characterisation and its potential for phosphorus removal. J Environ Manage 196: 119-126. [Crossref]

4. Wolter A, Scholz T, Liebau J (2017) Giant Rhinophyma: A Rare Case of Total Nasal Obstruction and Restitutio Ad Integrum. Aesthetic Plast Surg 41: 905-909. [Crossref]

5. Novati FC, Franchi A, Roggio T, Ramella V, Arnež ZM (2015) Treatment of a doublegiant Rhinophyma with electrocautery and Versajet hydrosurgery system. Ann Ital Chir 86: S2239253X15023269. [Crossref]

6. Sahin C, Turker M, Celasun B (2014) Giant rhinophyma: Excision with coblation assisted surgery. Indian J Plast Surg 47: 450-452. [Crossref]

7. Lazzeri D, Grassetti L, Torresetti M, Bottoni M, Scalise A, et al. (2013) Aesthetic refinement of the dog ear correction: the $90^{\circ}$ incision technique and review of the literature. Arch Plast Surg 40: 268-269. [Crossref]
8. Popa D, Osman G, Parvanescu H, Ciurea R, Ciurea M (2012) The treatment of giant rhinophyma - Case Report. Curr Health Sci J 38: 41-44. [Crossref]

9. Mangal M, Agarwal A, Jain H, Gupta A (2012) Giant rhinophyma of the nose. J Oral Maxillofac Surg 70: 376-377. [Crossref]

10. Mustafaev DM, Svistushkin VM (2011) A giant rhinophyma. Vestn Otorinolaringol: 68-69. [Crossref]

11. Akhdari N, Ettalbi S, Rachid M, Amal S (2009) Rhinophyma: a giant presentation. Clin Exp Dermatol 34: 536-537. [Crossref]

12. Köse R, Okur MI, Güldür ME (2008) Giant rhinophyma in a bronchial asthma patient treated by excision and full thickness skin grafting. Dermatol Online J 14: 9. [Crossref]

13. Nambi GI, Kumaran S, Gupta AK, Therese M (2008) An unusual type of basal cell carcinoma in a giant rhinophyma. J Plast Reconstr Aesthet Surg 61: 1400-1401. [Crossref]

14. Blairvacq JS, Yachouh J, Calteux N, Schmit S, Goudot P (2008) Otophyma, zygophyma and giant rhinophyma: a rare association. Ann Chir Plast Esthet 53: 441-447. [Crossref]

15. Sharma R, Pellerin D, Gaze DC, Gregson H, Streather CP, et al. (2005) Dobutamine stress echocardiography and the resting but not exercise electrocardiograph predict severe coronary artery disease in renal transplant candidates. Nephrol Dial Transplant 20: 2207-2214. [Crossref]

16. Racić G, Gluncić I, Tomić S, Petric S (1999) Giant rhinophyma--a case report Rhinology 37: 43-45. [Crossref]

17. Izu R, Gardeazabal J, Béjar J, Aguirre A, Díaz-Pérez JL (1994) A case of the elephant man phenotype with giant rhinophyma and benign symmetric lipomatosis. Clin Exp Dermatol 19: 531-533. [Crossref]

18. Giliarovskaia GB (1968) Giant rhinophyma in an 89-year-old patient. Zh Ushn Nos Gorl Bolezn 28: 106-107. [Crossref]

19. Debidour V (1952) Case of giant rhinophyma operated on with a free graft; results seven years later. Acta Derm Venereol 29: 310-312. [Crossref]

20. Rørdam OM, Guldbakke K (2011) Rhinophyma: big problem, simple solution. Acta Derm Venereol 91: 188-189. [Crossref]

21. Plenk HP (1995) Rhinophyma, associated with carcinoma, treated successfully with radiation. Plast Reconstr Surg 95: 559-562. [Crossref]

22. Bogetti P, Boltri M, Spagnoli G, Dolcet M (2002) Surgical treatment of rhinophyma: a comparison of techniques. Aesthetic Plast Surg 26: 57-60. [Crossref]

23. Lomeo PE, McDonald JE, Finneman J (2005) Obstructing rhinophyma: a case report. Otolaryngol Head Neck Surg 133: 799-800. [Crossref]

24. Tope WD, Sangueza OP (1994) Rhinophyma's fibrous variant. Histopathology and immunohistochemistry. Am J Dermatopathol 16: 307-310. [Crossref]

25. el-Azhary RA, Roenigk RK, Wang TD (1991) Spectrum of results after treatment of rhinophyma with the carbon dioxide laser. Mayo Clin Proc 66: 899-905. [Crossref]

26. Stucker FJ, Hoasjoe DK, Aarstad RF (1993) Rhinophyma: a new approach to hemostasis. Ann Otol Rhinol Laryngol 102: 925-929. [Crossref]

27. Har-El G, Shapshay SM, Bohigian RK, Krespi YP, Lucente FE (1993) The treatment of rhinophyma. 'Cold' vs laser techniques. Arch Otolaryngol Head Neck Surg 119: 628631. [Crossref]

Copyright: (C)2019 Cabrini G. This is an open-access article distributed under the terms of the Creative Commons Attribution License, which permits unrestricted use, distribution, and reproduction in any medium, provided the original author and source are credited. 